\title{
Granisetron Hydrochloride
}

National Cancer Institute

\section{Source}

National Cancer Institute. Granisetron Hydrochloride. NCI Thesaurus. Code C1353.

The hydrochloride salt of an indazole derivative with antiemetic properties. As a selective serotonin receptor antagonist, granisetron competitively blocks the action of serotonin at 5-hydroxytryptamine3 (5-HT3) receptors, resulting in the suppression of chemotherapy- and radiotherapy-induced nausea and vomiting. 